\title{
HUBUNGAN TINGKAT PENGETAHUAN IBU TENTANG DAMPAK KECELAKAAN PADA BALITA DI RUMAH DENGAN TINDAKAN PENCEGAHAN KECELAKAAN DI WILAYAH POSYANDU ALAMANDA 32 KECAMATAN PATRANG KABUPATEN JEMBER
}

\author{
Rita Sri Kurniawati \\ E-mail: ritasri.1207@gmail.com \\ Akademi Kebidanan Bina Husada Jember
}

\begin{abstract}
Abstrak
Kecelakaan adalah penyebab utama kematian dan kesakitan pada balita. Peran orang tua, khususnya ibu sangat penting untuk mencegah kecelakaan pada balita di rumah dengan memberikan pengawasan pada proses belajar dan bermain anak. Peningkatan pengetahuan pada ibu-ibu penting untuk mengurangi angka kejadian kecelakaan pada balita di rumah. Tujuan penelitian ini adalah untuk menganalisis hubungan tingkat pengetahuan ibu tentang dampak kecelakaan pada balita di rumah dengan tindakan pencegahan kecelakaan. Desain penelitian yang digunakan adalah analytic correlational dengan pendekatan cross sectional. Teknik sampling nonprobability sampling dengan jumlah sampel sebesar 82 orang. Data dikumpulkan menggunakan kuesioner dan dianalisis menggunakan Spearman Rank. Hasil uji statistik menunjukkan ibu dengan tingkat pengetahuan kurang sebanyak 15 orang $(18,3 \%)$, tingkat pengetahuan cukup sebanyak 33 orang $(40,2 \%)$ dan tingkat pengetahuan baik sebanyak 34 orang $(41,5 \%)$ dan pencegahan kecelakaan yang buruk sebanyak 41 orang $(50 \%)$ dan pencegahan kecelakaan yang baik sebanyak 41 orang (50\%). Nilai p sebesar 0,000 dan nilai $\mathrm{R}$ sebesar 0,530 yang menunjukkan ada hubungan dengan kekuatan sedang ke arah positif, yang berarti semakin tinggi tingkat pengetahuan ibu tentang dampak kecelakaan pada balita di rumah, semakin baik tindakan pencegahan kecelakaannya dan sebaliknya.
\end{abstract}

Kata Kunci: Tingkat Pengetahuan, Dampak, Pencegahan, Kecelakaan

\begin{abstract}
Unintentional injury is the main cause of morbidity and mortality among children. Parental role, especially mother is the most important to avoid unintentional injury among children by providing supervision in children playing and learning process. Increased knowledge among mothers is essential to reduce the unintentional injury incidence rate. The purpose of this study was to determine the correlation between mother's knowledge level about the impacts of unintentional injury in toddlers and preschool with unintentional injury prevention measures. The study design was analytic correlational with cross sectional approach. The sampling technique used nonprobability sampling with a sample size of 82 people. The data were collected using questionnaires and analyzed with Spearman Rank. The results showed that mother with a low level of knowledge as many as 15 people (18.3\%), sufficient level of knowledge as many as 33 people (40.2\%) and a good level of knowledge as many as 34 people $(41.5 \%)$ and mother with good injury prevention as many as 41 people (50\%) and poor injury prevention as many as 41 people (50\%). $P$ values of 0,000 and the $R$ value of 0,530 which showed an association with moderate strength and positive direction which meant that the higher the mother's knowledge level about the impacts of unintentional injury the better the unintentional injury prevention and vice versa.
\end{abstract}

Keywords: Knowledge Level, Impacts, Prevention, Unintentional Injury 


\section{PENDAHULUAN}

Kecelakaan menjadi masalah kesehatan umum yang terjadi di negara berkembang dan merupakan penyebab utama terjadinya kematian (Moshiro et al., 2005). Anak-anak merupakan merupakan kelompok usia yang rentan terhadap kecelakaan. Saat anak mencapai usia 5 tahun, kecelakaan atau cedera adalah ancaman terbesar dalam kehidupan mereka (World Health Organization, 2008). Kecelakaan dapat diartikan sebagai suatu kejadian yang tidak diharapkan dan tidak direncanakan, yang biasanya menyebabkan cedera, kematian dan kerusakan harta benda (Gupta, 2004).

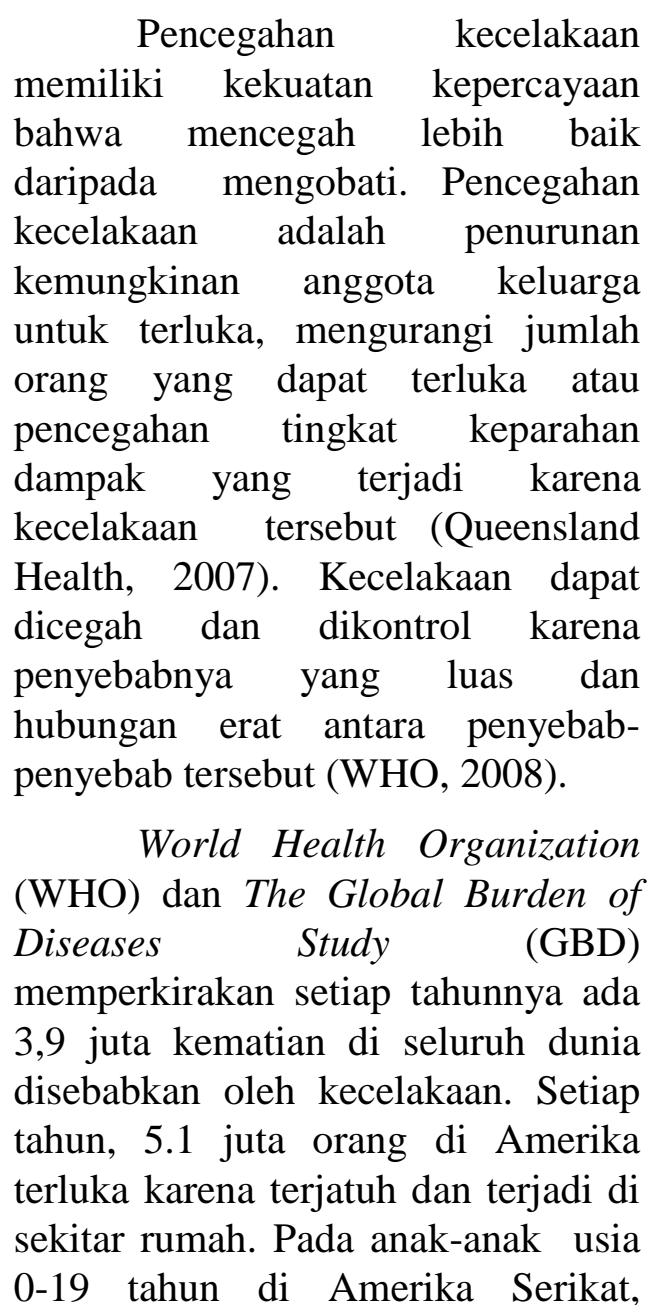

sebanyak 12.175 anak meninggal dunia karena kecelakaan di rumah setiap tahunnya (Casteel, et al., 2004). Di Eropa, 3-4 kematian dari 10 kematian terjadi pada anak-anak berusia 0-4 tahun. Kecelakaan tersebut juga terjadi pada 20.000 anak-anak berusia 1-14 tahun setiap tahunnya (Bruce, 2004). Di Inggris, Sekitar 900.000 anak-anak dan remaja di Inggris berusia dibawah 15 tahun dibawa rumah sakit akibat kecelakaan di rumah setiap tahunnya.

Korban kecelakaan yang tidak fatal akan mengalami nyeri yang parah dan harus menjalani perawatan jangka panjang. Kecelakaan juga menjadi penyebab utama kematian dan kecacatan di antara anak-anak di banyak negara Asia. Penelitian pada enam negara, yaitu Bangladesh, China, India, Filipina, Thailand dan Vietnam, menunjukkan angka kematian anak akibat kecelakaan sejumlah 700.000 anak setiap tahunnya (Flavin, 2006).

Data cedera akibat kecelakaan di Indonesia masih terbatas. Data cedera akibat kecelakaan masih bersifat lokal dan berbasis rumah sakit (IGD), laporan kasus di TKP (tempat kejadian perkara) dan Kepolisian. Belum ada data cedera yang berbasis populasi masyarakat dan untuk tingkat nasional. Atas dasar itu, diperlukan evidence based baseline data sehingga dapat dimanfaatkan untuk program pencegahan. Di Indonesia angka kematian anak akibat kecelakaan, keracunan dan trauma tercatat 7,3 \% (per 100.000) dan merupakan salah satu dari lima penyebab kematian anak tertinggi. Kecelakaan pada anak, sesuai data Riset Kesehatan Dasar (Riskesdas) 
Departemen Kesehatan tahun 2007 adalah sebesar $19,2 \%$ per 100.000 anak sedangkan kecelakaan lalu lintas jalan raya yang terjadi pada anak sesuai data dari Markas Besar Kepolisian Republik Indonesia (Mabes POLRI) tahun 2009 adalah sebesar 8.601 kasus. Kecelakaan menjadi penyebab utama kematian dan kecacatan pada anak-anak (Kementrian Kesehatan Republik Indonesia, 2009).

Keamanan anak terkait pencegahan kecelakaan adalah masalah kesehatan masyarakat yang harus mendapat perhatian khusus karena berpengaruh spesifik pada kesehatan anak (Harvey, et al., 2009). Tetapi pada kenyataannya menurut Morrongiello (2004), orang tua tidak menyadari risiko kecelakaan pada interaksi anak-anak dan orang tua sehari-hari, serta tidak mempunyai kepercayaan yang kuat dalam melakukan tindakan pencegahan. Balita merupakan kelompok yang rentan terhadap cedera. Hal ini terjadi karena balita masih dalam perkembangan neuromotorik, kognitif, fisik, sosiopsikologi dan sensori. Mereka masih dalam tahap perkembangan sistem motorik, belajar berjalan, lambat bereaksi, lapang pandang yang terbatas, tidak mampu menerima dua stimuli secara bersamaan, hiperaktivitas, kecenderungan meniru perilaku orang tuanya, dan selalu ingin tahu untuk belajar sesuatu yang baru (WHO, 2008; Otzurk, 2010).

Peningkatan status kesehatan merupakan salah satu bentuk dari peran perawat. Peningkatan status kesehatan dapat dilakukan dengan cara mengurangi resiko kecelakaan pada anak, diantaranya dengan bentuk prevensi primer. Prevensi primer dapat diberikan dengan cara promosi kesehatan melalui pemberian pendidikan kesehatan (Anderson \& Mc Farlane, 2006). Kecelakaan pada balita di rumah bisa dicegah melalui tindakan pencegahan kecelakaan yang dilakukan oleh orang tua di rumah, jadi orang tua harus bisa mengontrol dan mengawasi kondisi lingkungan, memperbaiki kondisi lingkungan yang berbahaya dimana anak-anak bermain dan tinggal. Pelatihan harus diberikan pada orang tua, khususnya ibu, mengenai cara mencegah kecelakaan di rumah, yang nantinya akan melindungi anak- anak kelompok usia 1-5 tahun dari kecelakaan (Morrongiello, 2010). Orang tua terutama ibu adalah orang yang terdekat dengan anak, dan ibu yang berkualitas adalah ibu yang berpendidikan tinggi (Nadia, 2008, dalam Islami, 2009).

Data yang didapatkan peneliti mengenai kunjungan UGD Puskesmas Patrang pada tahun 2017 (bulan Januari- November) menunjukkan bahwa angka kunjungan UGD karena kecelakaan umum pada usia anak (1-15 tahun) adalah 155 kunjungan, dengan 75 (48\%) kunjungan UGD adalah anak berusia 1-5 tahun, dan 80 (52\%) kunjungan lainnya adalah anak berusia 6-15 tahun. Total kunjungan UGD pada usia 1-5 tahun adalah 75 kunjungan, dengan pembagian 27 $(36 \%)$ kunjungan di antaranya karena kecelakaan lalu lintas, dan 48 (64\%) kunjungan di antaranya adalah karena kecelakaan di rumah. Data kecelakaan untuk usia anak di atas 
balita yaitu usia 6-15 tahun menunjukkan 80 kunjungan UGD karena kecelakaan umum, dengan 68 (85\%) kunjungan di antaranya adalah karena kecelakaan lalu lintas, dan 12 (15\%) kunjungan di antaranya adalah kecelakaan di rumah atau kecelakaan non lalu lintas. Berdasarkan data primer dari Puskesmas Patrang dan Pustu Slawu, bahwa Puskesmas tidak pernah mengadakan penyuluhan mengenai kecelakaan pada balita di rumah di wilayah Puskesmas Patrang, termasuk wilayah Posyandu Alamanda 32.

Berdasarkan uraian di atas, maka peneliti ingin melakukan penelitian tentang hubungan antara tingkat pengetahuan ibu tentang dampak kecelakaan pada balita di rumah dengan tindakan pencegahan kecelakaan di wilayah Posyandu Alamanda 32 Kecamatan Patrang Kabupaten Jember. Tujuan dari penelitian ini adalah mengidentifikasi karakteristik ibu dengan balita, mengidentifikasi tingkat pengetahuan ibu tentang dampak kecelakaan pada balita di rumah, mengidentifikasi tindakan pencegahan kecelakaan pada balita di rumah, menganalisis hubungan antara tingkat pengetahuan ibu tentang dampak kecelakaan kecelakaan pada balita di rumah dengan tindakan pencegahan kecelakaan di wilayah Posyandu Alamanda 32 Kecamatan Patrang Kabupaten Jember.

Manfaat dari penelitian ini antara lain menjadi aplikasi ilmu yang diperoleh selama perkuliahan bagi peneliti, menjadi sumber informasi dan tambahan literatur agar dapat meningkatkan kualitas perhatian bagi ranah keperawatan komunitas, maternitas dan anak mengenai pencegahan kecelakaan pada balita di rumah.

\section{METODE PENELITIAN}

Metode penelitian yang digunakan adalah korelasi dengan desain cross sectional dan variabel yang diukur dalam sekali waktu adalah pengetahuan ibu tentang dampak kecelakaan pada balita di rumah dengan tindakan pencegahan kecelakaan. Populasi penelitian ini adalah semua ibu yang memiliki anak balita di wilayah Posyandu Alamanda 32 Kecamatan Patrang Kabupaten Jember. Responden didapatkan melalui purposive sampling sebanyak 82 orang. Uji yang digunakan dalam menganalisis hubungan dua variabel pada penelitian ini adalah spearman rank dengan tingkat kemaknaan 95\% $(\alpha=0,05)$. 


\section{HASIL PENELITIAN}

Tabel 1: Distribusi Responden Berdasarkan Usia Ibu, Jumlah Anak, dan Usia Anak Balita pada Ibu Dengan Balita di wilayah Posyandu Alamanda 32 Kecamatan Patrang Kabupaten Jember Bulan November 2017 ( $\mathrm{n=82}$ )

\begin{tabular}{lcccc}
\hline \multicolumn{1}{c}{ Variabel } & Mean & Median & Modus & Min-Maks \\
\hline Usia Ibu (Tahun) & 29,66 & 30 & 30 & $16-47$ \\
Jumlah Anak & 2 & 2 & 2 & $1-7$ \\
Usia Anak (Bulan) & 26,96 & 26 & 26 & $12-56$ \\
\hline
\end{tabular}

Hasil analisis distribusi berdasarkan tabel 1 yaitu usia rata-rata ibu adalah 29.66 tahun. Sebagian besar responden berusia 28,42 hingga 30,90 tahun. Usia termuda responden adalah 16 tahun dan usia tertua responden adalah 47 tahun. Data jumlah anak menunjukkan jumlah anak rata-rata yang dimiliki ibu adalah 2 orang anak. Dengan jumlah anak paling sedikit adalah 1 dan jumlah anak paling banyak adalah 7 . Data usia anak balita menunjukkan rata-rata usia anak balita yaitu 26,96 bulan. Sebagian besar usia anak responden berkisar antara 24,57 hingga 29,36 bulan. Dengan usia anak balita termuda 12 bulan dan anak balita tertua 56 bulan.

Tabel 2: Distribusi Responden Berdasarkan Pendidikan, Pekerjaan dan Pola Pengasuhan Anak pada Ibu dengan Balita di Wilayah Posyandu Alamanda

32 Kecamatan Patrang Kabupaten Jember Bulan November 2017 ( $\mathrm{n=82}$ ).

\begin{tabular}{llcc}
\hline No & \multicolumn{1}{c}{ Variabel } & Jumlah & Persentase (\%) \\
\hline 1 & Tingkat Pendidikan & & \\
& SD & 17 & 20,7 \\
& SMP & 23 & 28 \\
& SMA & 30 & 36,6 \\
& Perguruan Tinggi & 12 & 14,6 \\
\hline \multicolumn{2}{l}{ Total } & 82 & 100 \\
\hline 2 & Status Pekerjaan Ibu & & \\
& Tidak Bekerja & 82 & 100 \\
& Bekerja & 0 & 0 \\
\hline Total & 82 & 100 \\
\hline 3 & Pola Pengasuhan Anak & & \\
& Diasuh Sendiri & 82 & 100 \\
& Diasuh Pembantu & 0 & 0 \\
Diasuh Keluarga & 0 & 0 \\
& Diasuh di Penitipan Anak & 0 & 0 \\
\hline & Total & 82 & 100 \\
\hline
\end{tabular}

Tabel 2 menunjukkan karakteristik responden berdasarkan beberapa kategori. Tingkatan pendidikan diukur berdasarkan lulusan pendidikan terakhir yang telah ditempuh oleh ibu dengan balita. 
Latar belakang pendidikan setiap responden bervariasi mulai dari SD, SMP, SMA dan PT. Data menunjukkan persentase pendidikan responden paling banyak adalah ibu dengan pendidikan SMA yaitu 30 orang $(36,6 \%)$ dan persentase pendidikan paling sedikit adalah pendidikan Perguruan Tinggi yaitu 12 orang $(14,6 \%)$. Status pekerjaan responden keseluruhan adalah responden yang tidak bekerja atau ibu rumah tangga yaitu 82 orang (100\%). Pada sebaran karakteristik responden pola pengasuhan anak, keseluruhan responden anaknya diasuh sendiri sejumlah 82 orang $(100 \%)$.

Tabel 3: Distribusi Responden Berdasarkan Tingkat Pengetahuan Ibu tentang Dampak Kecelakaan pada Balita di Rumah pada Ibu dengan Anak Balita di

Wilayah Posyandu Alamanda 32 Kecamatan Patrang Kabupaten Jember Pada Bulan November $2017(\mathrm{n}=82)$

\begin{tabular}{ccc}
\hline $\begin{array}{c}\text { Tingkat Pengetahuan tentang Dampak } \\
\text { Kecelakaan pada Balita di Rumah }\end{array}$ & Jumlah & Persentase \\
\hline Tingkat pengetahuan kurang & 15 & 18,3 \\
Tingkat pengetahuan cukup & 33 & 40,2 \\
Tingkat pengetahuan baik & 34 & 41,5 \\
\hline Total & 82 & 100 \\
\hline
\end{tabular}

Tabel 3 menunjukkan distribusi tingkat pengetahuan ibu dengan anak balita tentang dampak kecelakaan pada balita di rumah wilayah Posyandu Alamanda 32 Kecamatan Patrang Kabupaten Jember. Distribusi tingkat pengetahuan ibu terbanyak adalah tingkat pengetahuan baik yaitu 34 orang $(41,5 \%)$ dan paling sedikit adalah tingkat pengetahuan kurang yaitu 15 orang $(18,3 \%)$.

Tabel 4: Distribusi Responden Berdasarkan Tindakan Pencegahan Kecelakaan pada Ibu dengan Anak Balita di Wilayah Posyandu Alamanda 32 Kecamatan Patrang Kabupaten Jember Pada Bulan November 2017 (n=82)

\begin{tabular}{lcc}
\hline \multicolumn{1}{c}{ Pencegahan Kecelakaan } & Jumlah & Persentase \\
\hline Pencegahan kecelakaan buruk & 41 & 50 \\
Pencegahan kecelakaan baik & 41 & 50 \\
\hline Total & 82 & 100 \\
\hline
\end{tabular}

Tabel 4 menunjukkan distribusi tindakan pencegahan kecelakaan pada ibu dengan anak balita di wilayah Posyandu Alamanda 32 Kecamatan Patrang Kabupaten Jember. Tindakan pencegahan kecelakaan pada ibu dengan anak balita yang buruk sebanyak 41 orang $(50 \%)$ dan tindakan pencegahan kecelakaan pada ibu dengan anak balita yang baik sebanyak 41 orang 
Tabel 5: Distribusi Responden Berdasarkan Hubungan Tingkat Pengetahuan Ibu tentang Dampak Kecelakaan pada Balita di Rumah dengan Tindakan Pencegahan Kecelakaan Pada Ibu Dengan Anak Balita di Wilayah Posyandu Alamanda 32 Kecamatan Patrang Kabupaten Pada Bulan November 2017 (n=82)

\begin{tabular}{ccc}
\hline Variabel & P value & Nilai Korelasi \\
\hline $\begin{array}{c}\text { Tingkat Pengetahuan dan Pencegahan } \\
\text { kecelakaan }\end{array}$ & 0,000 & 0,530 \\
\hline
\end{tabular}

Nilai $\mathrm{p}$ pada tabel 5 tersebut menunjukkan bahwa $\mathrm{p}<\alpha(0,00<$ $0,05)$ maka dapat disimpulkan ada hubungan antara tingkat pengetahuan ibu tentang dampak kecelakaan pada balita di rumah dengan tindakan pencegahan kecelakaan pada ibu dengan anak balita di wilayah Posyandu Alamanda 32 Kecamatan Patrang Kabupaten Jember (Ha gagal ditolak). Kekuatan korelasi dapat dilihat melalui $r$ yaitu sebesar 0,530 yang memiliki arti bahwa kekuatan hubungan antar variabel adalah sedang. Arah korelasi pada hasil penelitian ini adalah positif (+) yang artinya semakin tinggi tingkat pengetahuan ibu tentang dampak kecelakaan pada balita di rumah maka semakin baik tindakan pencegahan kecelakaanya dan sebaliknya semakin rendah tingkat pengetahuan ibu tentang dampak kecelakaan pada balita di rumah maka semakin buruk pula tindakan pencegahan kecelakaannya di wilayah Posyandu Alamanda 32 Kecamatan Patrang Kabupaten Jember.

\section{PEMBAHASAN}

Ibu banyak yang mengetahui tentang risiko kecelakaan yang terjadi di dalam rumah, tetapi mereka tidak menyadari lingkup dari masalah kecelakaan pada anak dari interaksi mereka sehari-hari sehingga mereka menjadi lengah dalam mengawasi anak-anaknya dan tidak melakukan tindakan pencegahan kecelakaan di dalam rumah (Morrongiello, 2012). Motivasi merupakan penggerak perilaku, hubungan antara kedua konstruksi ini cukup kompleks. Motivasi mengarahkan perilaku pada tujuan tertentu (Notoatmodjo, 1993).

Hasil distribusi responden mengenai hubungan tingkat pengetahuan ibu tentang dampak kecelakaan pada balita di rumah dengan tindakan pencegahan kecelakaan di wilayah Posyandu Alamanda 32 Kecamatan Patrang Kabupaten Jember dapat dilihat pada tabel 5.5. hasil uji statistik dengan uji korelasi Spearman Rank menunjukkan nilai $\mathrm{p}<\alpha(0,000<$ $0,05)$ maka dapat disimpulkan terdapat hubungan antara tingkat pengetahuan tentang dampak kecelakaan pada balita di rumah dengan tindakan pencegahan kecelakaan di wilayah Posyandu Alamanda 32 Kecamatan Patrang Kabupaten Jember.

Arah korelasi pada hasil penelitian ini adalah positif (+) sehingga semakin tinggi tingkat pengetahuan tentang dampak kecelakaan pada balita di rumah, semakin baik pula pencegahan kecelakaannya, dan semakin rendah 
tingkat pengetahuan ibu tentang dampak kecelakaan pada balita di rumah, semakin buruk pula pencegahan kecelakaannya.

Meskipun hasil penelitian ini menunjukkan arah positif, namun kekuatan hubungan antar variabel menunjukkan kekuatan sedang. Oleh karena itu, pengetahuan yang dimiliki oleh ibu mengenai dampak kecelakaan pada balita lebih baik ditingkatkan bersama dengan peningkatan pengetahuan mengenai faktor-faktor resiko kecelakaan pada balita di rumah serta pengetahuan mengenai tindakan pencegahan kecelakaan yang perlu dilakukan.

$\begin{array}{ccc}\text { Berdasarkan uji } & \text { Spearman } \\ \text { Rank yang telah dilakukan, }\end{array}$
didapatkan kekuatan korelasi pada hasil penelitian ini adalah 0,530. Hasil tersebut berada di antara 0,400 - 0,599 yang berarti menunjukkan ada hubungan yang sedang antara tingkat pengetahuan ibu tentang dampak kecelakaan pada balita di rumah dengan tindakan pencegahan kecelakaan di wilayah Posyandu Alamanda 32 Kecamatan Patrang Kabupaten Jember. Hal ini memiliki arti bahwa sebesar

$\begin{array}{ccc}53,0 \% & \text { variabel tingkat } \\ \text { pengetahuan } & \text { tentang }\end{array}$ kecelakaan pada balita di rumah menentukan tindakan pencegahan kecelakaan dan sisanya sebesar 47,0\% menunjukkan bahwa tindakan pencegahan kecelakaan pada balita di rumah masih dipengaruhi oleh faktor-faktor lain selain tingkat pengetahuan tentang dampak kecelakaan pada balita di rumah, yaitu pendidikan, usia ibu, jumlah anak, usia anak dan lingkungan.
Faktor-faktor

yang mempengaruhi untuk terjadinya perilaku salah satunya adalah tingkat pengetahuan (Notoatmodjo, 2007).

Hasil penelitian menunjukkan bahwa sebanyak 15 ibu dengan balita memiliki tingkat pengetahuan yang kurang dan 33 ibu yang memiliki tingkat pengetahuan cukup. Sesuai dengan hasil uji statistik yang menyatakan ada hubungan antara tingkat pengetahuan tentang dampak kecelakaan pada balita di rumah dengan tindakan pencegahan kecelakaan, maka ada kecenderungan ibu dengan pengetahuan yang kurang tidak melakukan tindakan pencegahan kecelakaan secara baik. Sehingga jumlah ibu dengan tingkat pengetahuan kurang dan cukup memiliki kemungkinan tergolong pada 41 ibu dengan tindakan pencegahan kecelakaan buruk. Tingkat pengetahuan ibu akan mempengaruhi pembentukan perilaku pencegahan kecelakaan pada balita di rumah. Tingkat pengetahuan yang rendah tersebut mempengaruhi perhatian ibu terhadap masalah kecelakaan pada balita sehingga membuat kurangnya perhatian ibu terhadap tindakan pencegahan kecelakaan pada balita.

Motivasi ibu untuk melakukan tindakan pencegahan kecelakaan masih terkait dengan faktor-faktor pengalaman, pendidikan, keterpaparan informasi, daya tangkap terhadap informasi dan lingkungan sekitar yang mempengaruhi ibu dalam mengambil keputusan terkait tindakan pencegahan kecelakaan pada balita di rumah. 


\section{Green}

mengungkapkan

bahwa

pembentukan perilaku didasari oleh faktor predisposisi, faktor pemungkin dan faktor penguat. Faktor predisposisi sendiri terdiri dari pengetahuan, kepercayaan, nilai budaya dan karakteristik individu. Faktor pemungkin antara lain ketersediaan layanan dan aturan yang berlaku. Faktor penguat antara lain keuntungan, hambatan, pendapat dan kritik. Dalam penelitian ini tingkat pengetahuan tentang dampak kecelakaan pada balita di rumah membentuk suatu faktor predisposisi bagi ibu untuk melakukan suatu tindakan pencegahan. Hasil penelitian menunjukkan terdapat 33 ibu dengan pengetahuan yang cukup dan $34 \mathrm{ibu}$ dengan pengetahuan yang baik. Ibu dengan tingkat pengetahuan yang baik mengenai dampak kecelakaan pada balita di rumah akan memiliki motivasi yang jauh lebih tinggi untuk melakukan tindakan pencegahan kecelakaan pada balita di rumah. Hal ini memberikan kemungkinan kecenderungan ibu dengan tingkat pengetahuan yang cukup dan baik akan tergolong juga pada ibu yang memiliki tindakan pencegahan kecelakaan baik yang sejumlah 41 orang.

Tingkat pengetahuan ibu yang cukup dan baik tidak terpaut jauh dalam hal selisih angka, namun sesuai dengan hasil penelitian golongan tersebut terbagi menjadi dua golongan tindakan pencegahan kecelakaan yang baik dan pencegahan kecelakaan buruk yang memiliki jumlah sama. Hal ini menunjukkan bahwa faktor pemungkin dan faktor penguat juga memiliki peran penting dalam menentukan suatu pembentukan perilaku.

Faktor pemungkin yang menentukan pembentukan perilaku ibu untuk melakukan tindakan pencegahan kecelakaan antara lain pengetahuan tentang petunjuk melakukan tindakan dan kepercayaan diri. Sedangkan faktor yang menguatkan ibu untuk melakukan tindakan pencegahan antara lain hambatan yang dirasakan dan persepsi keuntungan yang akan didapatkan. Ibu dengan tingkat pengetahuan baik, memiliki persepsi keuntungan bahwa dengan melakukan tindakan pencegahan kecelakaan akan memberikan perlindungan kepada anak balita, sehingga menimbulkan motivasi ibu untuk melakukan tindakan pencegahan. Namun, hambatan yang dirasakan ibu mungkin mempengaruhi ibu untuk tidak melakukan tindakan pencegahan kecelakaan secara baik. Ibu dengan tingkat pengetahuan cukup juga dapat mengalami perbedaan satu sama lain dalam pembentukan perilakunya terkait faktor pemungkin dan faktor penguat tersebut, hal tersebut memberikan kekuatan motivasi yang berbeda pada tiap-tiap ibu dan menghasilkan tindakan pencegahan kecelakaan yang berbeda.

Hal ini sesuai dengan teori Health Belief Model bahwa perilaku sehat didapatkan dari persepsi terhadap risiko (kerentanan dan keparahan), evaluasi terhadap hambatan, dan keuntungan, petunjuk tindakan serta kepercayaan diri (Glanz, 1997, dalam Morrongiello, 2012). 
Poorolajal, et al. (2013) juga menyatakan hal yang sama mengenai pencegahan kecelakaan pada balita di rumah yaitu pengetahuan tentang risiko terjadinya cedera, persepsi tentang keparahan cedera, keuntungan yang didapatkan, hambatan yang dirasakan, petunjuk tindakan dan kepercayaan diri merupakan faktor terpenting dalam mengkonstruksikan suatu perilaku pencegahan kecelakaan pada balita di rumah. Sehingga jika ibu mengetahui risiko dan dapat mempersepsikan keparahan cedera dari sebuah kecelakaan maka akan menentukan motivasi dan sikap ibu untuk melakukan tindakan pencegahan kecelakaan pada balita di rumah. Tetapi banyak juga ibu yang mengetahui tentang risiko kecelakaan yang terjadi di dalam rumah, tetapi mereka tidak menyadari lingkup dari masalah kecelakaan pada anak dari interaksi mereka sehari-hari sehingga mereka menjadi lengah dalam mengawasi anak-anaknya dan tidak melakukan tindakan pencegahan kecelakaan di rumah (Morrongiello, 2012).

Ibu dengan tingkat pengetahuan rendah tidak memahami hal-hal yang memiliki dampak serius pada balita terkait kecelakaan yang terjadi, sehingga tingkat motivasi yang timbul untuk melakukan tindakan pencegahan kecelakaan juga rendah. Ibu yang tidak tidak memahami dampak kecelakaan pada balita yang dapat membahayakan balita akan mengacuhkan faktorfaktor resiko yang dapat menjadi penyebab kecelakaannya. Ibu dapat membahayakan anak balita dengan mengacuhkan faktor-faktor penyebab kecelakaan dan bermanifestasi pada tidak dilakukannya tindakan pencegahan kecelakaan yang menyebabkan anak balita berisiko lebih tinggi untuk mengalami kecelakaan di rumah dan berisiko lebih tinggi pula untuk terkena dampak kecelakaan yang lebih parah.

Pelatihan perlu diberikan pada orang tua, khususnya ibu, mengenai cara mencegah kecelakaan di rumah, yang nantinya akan melindungi anakanak kelompok usia 1-5 tahun dari kecelakaan (Morrongiello, 2010). Ibu memiliki peran primer dalam peningkatan kesehatan anak melalui perilaku pencegahan kecelakaan di rumah dan melindungi anak-anak dari kecelakaan di rumah. Ibu tidak menyediakan perawatan ini sendiri, namun membutuhkan bantuan dan dukungan dari sumber lain dalam praktiknya. Jadi, perawat kesehatan komunitas harus memberikan pelatihan pada orang tua, khususnya pada ibu mengenai cara pencegahan kecelakaan (Anusha, 2010).

Fenomena yang terjadi di wilayah Posyandu Alamanda 32 dan juga wilayah kerja Puskesmas Patrang Kabupaten Jember adalah masyarakat tidak pernah mendapatkan informasi ataupun promosi kesehatan terkait faktor risiko, dampak dan petunjuk tindakan pencegahan kecelakaan bata balita di rumah. Hal ini menunjukkan bahwa masalah kecelakaan pada balita di rumah belum mendapatkan perhatian khusus dari tim pelayanan kesehatan di wilayah Puskesmas Patrang. Masyarakat memerlukan adanya suatu peran perawat dalam komunitas dalam upaya peningkatan pengetahuan terkait faktor resiko kecelakaan, dampak kecelakaan, dan 
tindakan pencegahan kecelakaan pada balita di rumah.

Keperawatan merupakan suatu bentuk pelayanan profesional yang merupakan bagian integral dari pelayanan kesehatan didasarkan pada ilmu dan kiat keperawatan, berbentuk pelayanan berbentuk pelayanan bio-psiko-sosio- spiritual yang komprehensif, diajukan pada individu, keluarga, dan masyarakat baik sakit maupun sehat yang mencakup seluruh proses kehidupan manusia (Lokakarya Nasional Keperawatan dalam Mubarak, 2007). Dalam hal ini, perawat dapat berkerja dengan berkoordinasi dengan kesehatan masyarakat ataupun mahasiswa sekolah keperawatan untuk melakukan pendekatan kepada masyarakat dan memberikan seluruh informasi terkait faktor resiko kecelakaan, dampak kecelakaan, dan tindakan pencegahan kecelakaan pada balita di rumah.

\section{SIMPULAN DAN SARAN}

\section{Simpulan}

Simpulan yang dapat diambil pada penelitian ini adalah:

1. Usia termuda responden adalah 16 tahun dan usia tertua responden adalah 47 tahun, pendidikan ibu terbanyak adalah ibu dengan pendidikan SMA yaitu sebanyak 30 orang $(36,6 \%)$, jumlah anak rata-rata adalah 2 orang, usia anak balita rata-rata 26,9 bulan, status pekerjaan ibu keseluruhan adalah ibu rumah tangga yaitu sebanyak 82 orang (100\%), dan pola pengasuhan anak seluruhnya diasuh sendiri yaitu sejumlah 82 orang (100\%).

2. Distribusi tingkat pengetahuan ibu tentang dampak kecelakaan pada balita di rumah di wilayah Posyandu Alamanda 32 Kecamatan Patrang Kabupaten Jember, ibu yang memiliki tingkat pengetahuan kurang sebanyak 15 orang $(18,3 \%)$ dan ibu yang memiliki pengetahuan yang cukup sebanyak 33 orang $(40,2 \%)$ serta ibu yang memiliki pengetahuan baik sebanyak 34 orang $(41,5 \%)$.

3. Distribusi tindakan pencegahan kecelakaan pada ibu dengan anak balita di wilayah Posyandu Alamanda 32 Kecamatan Patrang Kabupaten Jember, pencegahan kecelakaan pada balita yang buruk sebanyak 41 orang $(50 \%)$ dan pencegahan kecelakaan pada balita yang baik sebanyak 41 orang $(50 \%)$.

4. Ada hubungan antara tingkat pengetahuan ibu tentang dampak kecelakaan pada balita di rumah dengan tindakan pencegahan kecelakaan pada ibu dengan anak balita di wilayah Posyandu Alamanda 32 Kecamatan Patrang Kabupaten Jember dengan nilai $\mathrm{p}$ value $=0,000$ dan kekuatan korelasi sedang yaitu sebesar 0,530.

\section{Saran}

Saran yang diberikan terkait dengan hasil dan pembahasan dalam penelitian ini adalah sebagai berikut:

1. Bagi Peneliti

Dengan hasil penelitian yang telah didapatkan, diharapkan dapat menambahkan 
pengetahuan peneliti sehingga dapat melakukan penerapan ilmu keperawatan dengan lebih baik, serta menambahkan pengetahuan dalam asuhan keperawatan maternitas anak dalam komunitas.

2. Bagi Institusi Pendidikan

Tindakan pencegahan kecelakaan pada balita di rumah dipengaruhi oleh beberapa faktor salah satunya tingkat pengetahuan. Oleh karena itu, saran bagi institusi pendidikan adalah peningkatan peran serta secara langsung dalam pemberian informasi dan promosi kesehatan pada masyarakat sebagai salah satu realisasi pengabdian institusi pendidikan pada masyarakat. Serta saran bagi penelitian selanjutnya adalah melakukan penelitian terkait promosi kesehatan pada ibu dengan anak balita mengenai risiko kecelakaan, dampak kecelakaan, dan petunjuk pencegahan kecelakaan pada balita di rumah dalam pengaruhnya terhadap tindakan pencegahan kecelakaan pada balita.

3. Bagi Institusi Pelayanan

Penelitian ini menambahkan data dan informasi mengenai kecelakaan pada balita di rumah di wilayah Posyandu Alamanda 32 dan termasuk wilayah kerja Puskesmas Patrang Kabupaten Jember. Perawat dan tenaga kesehatan lainnya di komunitas diharapkan dapat meningkatkan perhatian untuk masalah kecelakaan pada balita di rumah dengan peningkatan pemberian informasi dan promosi kesehatan terkait resiko kecelakaan, dampak kecelakaan dan upaya pencegahan kecelakaan pada balita di rumah.

4. Bagi Masyarakat

Responden dalam penelitian ini adalah ibu dengan anak balita diharapkan lebih memperhatikan kesehatan dan keselamatan balita terkait perihal kecelakaan pada balita. Keluarga dan suami diharapkan turut bekerja sama dalam memberikan pengawasan serta modifikasi lingkungan rumah, sarana bermain dan lingkungan bermain anak yang dapat memberikan keamanan pada anak balita dari kecelakaan di rumah

\section{DAFTAR PUSTAKA}

Anderson, E.T. \& Mc. Farlane, J. 2006. Buku Ajar Keperawatan Komunitas: Teori dan praktek (edisi 3). Jakarta: EGC.

Anusha, G. P. 2010. A Study To Assess The Effectiveness Of Sim On Knowledge Regarding Selected Home Accident And Its Prevention Among Mothers Of Under Five Children At Selected Villages, Mangalore, Rajiv Gandhi University of Health Sciences, Karnataka, Mangalore.

Flavin, Michael. 2006. Stages of development and injury pattern in the early years, BMC Public Health. [serial online]. (http/www.ncbi.nlm.nih.gov/pu bmed/16848890, diakses tanggal 30 Oktober 2017) 
Glanz, K., Marcus Lewis, F. \& Rimer, B.K. (1997). Theory at a Glance: A Guide for Health Promotion Practice. National Institute of Health

Gupta, K.R. \& Gupta, R. 2004. Home Related Accidents during Infancy, JK Science. [serial online]. (http://www.jkscience.org/arch ive/volume62/home, diakses tanggal 30 Oktober 2017.

Kementrian Kesehatan Republik Indonesia. 2009. Pencegahan Kecelakaan Pada Anak [serial onine]. (http://www.promkes.depkes.g o.id/index.php/topikkesehatan/70-pencegahankecelakaan-pada-anak, diakses tanggal 20 September 2017).

Morrongiello. 2004. Mothers' Home-Safety Practices For Preventing Six Types Of Childhood Injuries: What Do They Do, And Why?. Journal of Pediatric Psychology 29(4) : 285-297.

Morrongiello, $\mathrm{AB} \&$ Kiriakou, S. 2010. Mothers' Home- Safety Practices for Preventing Six Types of Childhood Injuries. Journal of Pediatrics Psychology. [serial online]. (http://jpepsy.oxfordjournals.or g/content/29/4/285, diakses tanggal 30 Oktober 2017)

Moshiro, et al. 2005. Injury Morbidity in An Urban and A Rural Area in Tanzania: An Epidemiological Survey. [serial online]. (http://www.bio medcentral.com/content/pdf/14

71-2458-5-11.pdf, diakses tanggal 30 Oktober 2017).

Mubarak, Wahid Iqbal,dkk. 2007. Promosi Kesehatan Sebuah Metode Pengantar Proses Belajar Mengajar dalam Pendidikan. Yogyakarta: Graha Ilmu.

Notoatmojo. 1993. Pengantar Pendidikan Kesehatan Dan Ilmu Perilaku Kesehatan. Yogyakarta: Andi offset.

Notoatmodjo. 2003. Pendidikan dan Perilaku Kesehatan. Jakarta: Rineka Cipta

Otzurk. 2010. Home Accidents And Mothers Measurements In Preschool Children. Anatolian Journal Clinical Investigation 4(1):15-21.

Poorolajal, Jalal, et al. 2013. Factors Associated with Mothers' Beliefs and Practices Concerning Injury Prevention in Under Five-Year Children, Based on Health Belief Model. [serial online]. (www.umsha.ac.ir/jrhs, diakses pada tanggal 30 Oktober 2017).

Queensland Health. 2007. Definitions-What Is Injury. [serial online]. (http://www.health.qld.gov.au/ chipp/ what_is/definitions.asp, diakses tanggal 20 Oktober 2017).

Who. 2007. Preventing Injuries And Violence, A Guide For Ministries Of Health. [serial online]. (http://www.who.int/violence_i njury_prevention/ publications/injury_policy_pla 
nning/prevention_moh/e

n/index.html, diakses tanggal

20 Oktober 2017).

WHO. 2008. World Report Of Child Injury Prevention. [serial online].

(http://www.who.int/violence_i njury_

prevention/child/injury/world_r eport/en/ diakses tanggal 20Oktober 2017). 